\title{
INFLUENCE OF CONTROLLED FORGING AND COOLING ON THE MICROSTRUCTURE OF NON-QUENCHED AND TEMPERED 1538MV STEEL FOR CRANKSHAFTS
}

\author{
VPLIV KONTROLIRANEGA KOVANJA IN TEHNOLOGIJE \\ OHLAJEVANJA NA MIKROSTRUKTURO NEKALJENEGA IN \\ POPUŠČENEGA JEKLA 1538MV ZA ROČIČNE GREDI
}

\author{
Yang Yong ${ }^{1,2}$, Zhou Le-yu², Jiang Peng², Ren Xue-ping1, Liang Pei-xin² \\ ${ }^{1}$ School of Materials Science and Technology, University of Science \& Technology Beijing, no. 30 Xue Yuan Road, Hai Dian District, \\ Beijing 100083,China \\ ${ }^{2}$ Beijing Research Institute of Mechanical \& Electrical Technology, Forging Technology Center, no. 18 Xue Qing Road, Hai Dian District, \\ Beijing 100083, China \\ yy19821110@163.com
}

Prejem rokopisa - received: 2018-06-01; sprejem za objavo - accepted for publication: 2018-08-02

doi: $10.17222 /$ mit.2018.112

\begin{abstract}
The effects of forging and the cooling parameters on the microstructure of non-quenched and tempered $1538 \mathrm{MV}$ steel were studied using thermal simulation tests. With an increase of the deformation and a decrease of the deformation temperature, the austenite grains were refined, and the volume fraction of ferrite improved. With the increasing of the cooling rate, the austenite grain growth is significantly restrained, and the pearlite lamellar spacing is refined simultaneously. Therefore, the cooling process should be strictly controlled after forging. The cooling rate before the ferrite phase transition should be fast, while that during the phase transition should be slow. This is beneficial to the refinement of the microstructure and the full formation of ferrite, and the abnormal microstructures, such as bainite and martensite, are avoided. The numerical simulations show that the deformation of the finished forging process is very important for the filling of the die cavity and non-overloading of the equipment. The deformation of the finished forging should be reasonable, and the deformation temperature should not be too low. The above research results provide an important basis for the optimization of the forging and the cooling process for non-quenched and tempered $1538 \mathrm{MV}$ steel.
\end{abstract}

Keywords: non-quenched and tempered steel, controlled forging, controlled cooling, microstructure, crankshafts

Avtorji članka so s preizkusi na termičnem simulatorju raziskovali vpliv tehnoloških parametrov kovanja in ohlajanja na mikrostrukturo nekaljenega in popuščenega jekla 1538MV. Ugotovili so, da z naraščajočo stopnjo deformacije in zniževanjem temperature deformacije pride do udrobljenja austenitnih zrn in izboljšanja volumskega deleža ferita. Z naraščajočo hitrostjo ohlajanja pa je znatno zavrta rast austenitnih zrn in istočasno zmanjšana razdalja med perlitnimi lamelami. Zato moramo proces ohlajevanja po kovanju absolutno kontrolirati. Ohlajevalna hitrost pred prehodom v feritno fazo mora biti velika, medtem ko mora biti fazni prehod počasen. To je koristno za udrobljenje mikrostrukture in popolno tvorbo ferita in s tem se izognemo tvorbi $v$ tem primeru neželenih mikrostruktur, kot sta bainit in martenzit. Numerična simulacija je pokazala, da je deformacija na koncu procesa kovanja zelo pomembna za zapolnjenje votline kovaškega orodja z materialom in nepretirano obremenitev opreme (kovaškega stroja in orodja). Deformacija na koncu kovanja mora biti ustrezna in temperatura deformacije ne sme biti prenizka. Predstavljeni rezultati raziskave predstavljajo pomembno osnovo za optimizacijo kovanja in procesa ohlajanja za nekaljeno in popuščeno jeklo 1538MV.

Ključne besede: nekaljeno in popuščeno jeklo, kontrolirano kovanje, kontrolirano ohlajanje, mikrostruktura, ročične gredi

\section{INTRODUCTION}

Non-quenched and tempered (NQ\&T) steel can match the mechanical properties of quenched and tempered steels by adding micro-alloying elements $(\mathrm{V}, \mathrm{Nb}$, Ti, etc.). The NQ\&T steel is a kind of energy-saving and environment-friendly steel. ${ }^{1-4}$ At present, in order to replace the traditional quenched and tempered steel, the NQ\&T steel has been widely used to produce automotive engine crankshafts..$^{5-8}$ The comprehensive properties of the NQ\&T steel can be obtained by changing the chemical composition. But for a certain chemical composition of the steel, the effective way is to control the forging and cooling technology. ${ }^{9-13}$ The controlled forging and cooling of NQ\&T steel are receiving more and more attention.

The effect of controlled cooling after forging on the formation of intragranular ferrite for a medium-carbon steel was investigated by analyzing its microstructure, tensile properties, impact toughness and fracture. ${ }^{14}$ The effect of the thermo-mechanical control process on the microstructure and mechanical properties of a nonquenched and tempered steel were discussed. ${ }^{15}$ The influence of the heating temperature and controlled cooling on the microstructure and properties of a nonquenched and tempered steel was studied by heat treatment. ${ }^{16}$ The effects of controlled forging and the cooling technique on the refinement of the microstructure and the precipitation behavior of carbo-nitrides and intra- 
Y. YONG et al.: INFLUENCE OF CONTROLLED FORGING AND COOLING ON THE MICROSTRUCTURE ...

Table 1: Chemical composition

\begin{tabular}{|c|c|c|c|c|c|c|c|c|c|}
\hline \multirow{3}{*}{ Alloy } & \multicolumn{9}{|c|}{ Elements $(w / \%)$} \\
\hline & & $\mathrm{C}$ & $\mathrm{Si}$ & $\mathrm{Mn}$ & $\mathrm{P}$ & S & $\mathrm{Cr}$ & $\mathrm{V}$ & $\mathrm{N}$ \\
\hline & measured value & 0.38 & 0.56 & 1.39 & $\max .0 .015$ & 0.61 & 0.16 & 0.08 & 0.011 \\
\hline
\end{tabular}

granular ferrite (IGF) are discussed. ${ }^{17}$ The influence of the alloying element and the cooling rate on the continuous cooling transformation of supercooled austenite was discussed. ${ }^{18}$ The effect of different cooling rates on the microstructure, tensile strength and impact toughness of a non-quenched and tempered steel was studied. ${ }^{19}$ The effect of post-forging controlled cooling on the microstructure and hardness of a kind of medium-carbon high-vanadium micro-alloyed steel for fracture splitting of a connecting rod was investigated using a Gleeble3800 thermal simulator. ${ }^{20}$

The pearlitic+ferritic NQ\&T steel is used more widely in crankshafts. ${ }^{21-22}$ Under continuous mass production, the main problem with crankshafts is the lack of a system for the forging and cooling process. It is necessary to achieve the purpose of controlling the forming and properties of crankshaft forging. The forging process of NQ\&T 1538MV steel for crankshafts was simulated with a mechanical simulator, and the influence of the controlled forging and cooling process on the microstructure was studied in this paper. The optimized forging process with respect to NQ\&T $1538 \mathrm{MV}$ steel for a crankshaft was obtained by numerical simulation, and the experimental data provided the basis for the optimization of the forging and cooling process for NQ\&T 1538MV steel.

\section{EXPERIMENTAL PART}

The 1538MV rolled bars for the investigation were taken from a forging workshop. The diameter of the rolled bar was $85 \mathrm{~mm}$. Cylindrical samples with a size of $\varphi 8 \times 16 \mathrm{~mm}$ were cut at the $1 / 2$ radius of the rolled bar.

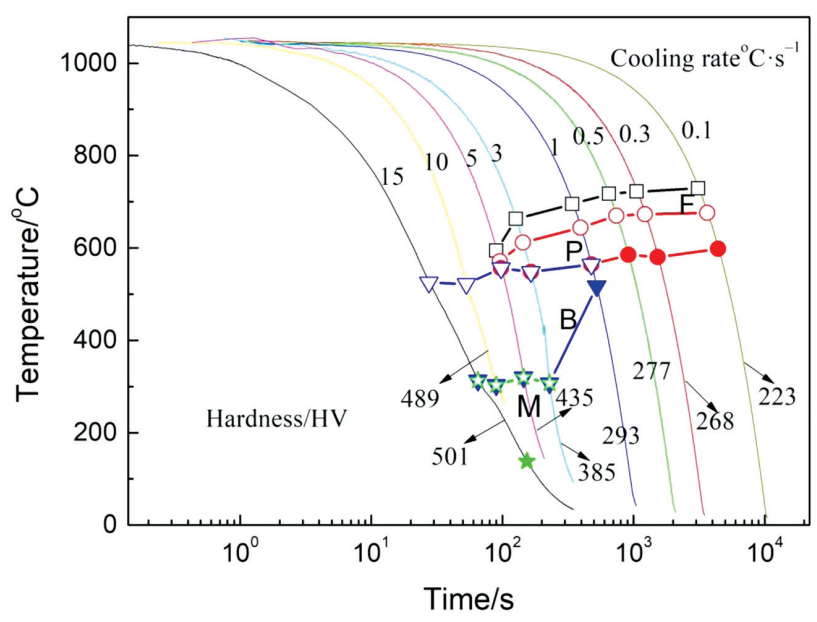

Figure 1: Dynamic CCT curves of the tested steel
The chemical composition of the rolled bar is shown in Table 1.

The thermal simulation tests were performed with a Gleeble 3500. The samples were taken from the middle deformation part. They were polished and etched with $4 \%$ nital, then the microstructure was observed. The experimental instruments were a ZEISS AxioScopeA1 optical microscope and a JZeiss Gemini 500 scanning electron microscope. The hardness of the tested steel was tested with a LEICAVMHT30M Vickers hardness tester.

The samples were heated to $1200{ }^{\circ} \mathrm{C}$ at a rate of $10{ }^{\circ} \mathrm{C} \mathrm{s}^{-1}$ and then cooled to $1050{ }^{\circ} \mathrm{C}$ at a rate of $10{ }^{\circ} \mathrm{C} \mathrm{s}^{-1}$ after $5 \mathrm{~min}$ of heat preservation. After $30 \%$ deformation with a strain rate of $0.1 \mathrm{~s}^{-1}$, the samples were cooled at different rates to room temperature, and the temperature-expansion curves were recorded. The dynamic CCT curves for the steel are shown in Figure 1.

The following data were provided by the forging workshop. The forging temperature of the crankshaft is usually from $1100{ }^{\circ} \mathrm{C}$ to $1180{ }^{\circ} \mathrm{C}$. The lower forging temperature is beneficial to the microstructure refinement and the ferrite formation, but not conducive to the filling of the cavity. The crankshaft surface cooling rate after forging is usually from $0.3{ }^{\circ} \mathrm{C} \mathrm{s}^{-1}$ to $0.5{ }^{\circ} \mathrm{C} \mathrm{s}^{-1}$, but the cooling rate of the crankshaft core is less than $0.3{ }^{\circ} \mathrm{C} \mathrm{s}^{-1}$. The shape of the crankshaft is complex, the deformation of each section is not uniform, and the deformation of each section is different. Based on the above, the experimental scheme is shown in Table 2.

Table 2: Parameters of the thermal simulation

\begin{tabular}{|c|c|c|c|}
\hline $\begin{array}{c}\text { Temperature } \\
/{ }^{\circ} \mathrm{C}\end{array}$ & $\begin{array}{c}\text { Strain rate } \\
/ \mathrm{s}^{-1}\end{array}$ & $\begin{array}{c}\text { Deformation } \\
/ \%\end{array}$ & $\begin{array}{c}\text { Cooling rate } \\
/{ }^{\circ} \mathrm{C} \mathrm{s}^{-1}\end{array}$ \\
\hline 1150 & 10 & $5,10,30,50$ & $0.3{ }^{\circ} \mathrm{C} \mathrm{s}^{-1}$ \\
\hline $\begin{array}{c}1050,1100, \\
1150\end{array}$ & 10 & 50 & $0.3{ }^{\circ} \mathrm{C} \mathrm{s}^{-1}$ \\
\hline 1150 & 10 & 50 & $\begin{array}{c}0.1{ }^{\circ} \mathrm{C} \mathrm{s}^{-1} \\
0.3{ }^{\circ} \mathrm{C} \mathrm{s}^{-1} \\
1{ }^{\circ} \mathrm{C} \mathrm{s} \mathrm{s}^{-1}\end{array}$ \\
\hline
\end{tabular}

\section{RESULTS AND DISCUSSION}

\subsection{Influence of deformation}

The microstructures of the different deformations are shown in Figure 2, and the statistical results are shown in Figure 3. The microstructure consists of ferrite and pearlite, and ferrite mainly formed on the austenite grain boundaries and distributed like a net. When the deformation increased from $5 \%$ to $50 \%$, the average grain size of the austenite was refined from $149.9 \mu \mathrm{m}$ to 


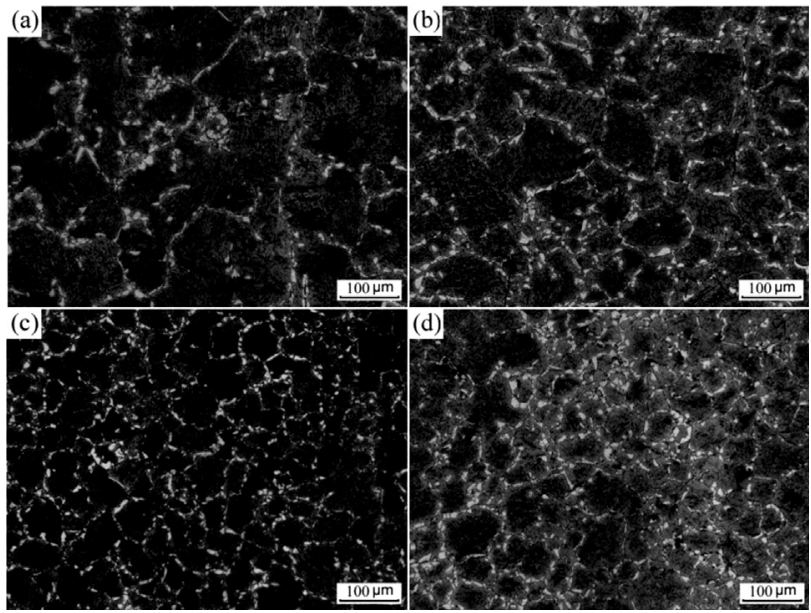

Figure 2: Microstructures of the different deformations: a) deformation $5 \%, b$ ) deformation $10 \%$, c) deformation $30 \%$, d) deformation $50 \%$

$55.6 \mu \mathrm{m}$, and the volume fraction of ferrite increased from $6.1 \%$ to $11.3 \%$.

With the increasing of the deformation, the austenite grain size was refined by recrystallization. When the deformation increased to $30 \%$, the average grain size of the austenite decreased sharply. Therefore, it can be deduced that the thermal deformation of the material has a critical value. To obtain refined grains, the critical value of the deformation must be reached. With the refinement of the austenite grains, the grain-boundary area increased. As a result, the nucleation sites of the ferrite increased, and the volume fraction of the ferrite increased simultaneously.

\subsection{Influence of temperature}

The microstructures for the different deformation temperatures are shown in Figure 4, and the statistical results are shown in Figure 5. The microstructure consists of ferrite and pearlite. With the increasing of the deformation temperature, the average grain size of the austenite increased from $57.4 \mu \mathrm{m}$ to $109 \mu \mathrm{m}$, and the volume fraction of ferrite decreased from $12.3 \%$ to $6.9 \%$.

With the increasing of the deformation temperature, the austenite grain size increased significantly. When the deformation temperature was $1050{ }^{\circ} \mathrm{C}$, the austenite grains were fine and uniform. But when the temperature was $1150{ }^{\circ} \mathrm{C}$, the austenite grains were obviously coarse. At low temperature, the austenite was refined by crystallization, and the grain-boundary area increased. Many crystal defects such as dislocations and vacancies could be formed by the low deformation temperature. The carbo-nitride of $\mathrm{V}$ and $\mathrm{Ti}$ increased because of the induced deformation, and the grain refinement was enhanced. With the increasing of the temperature,

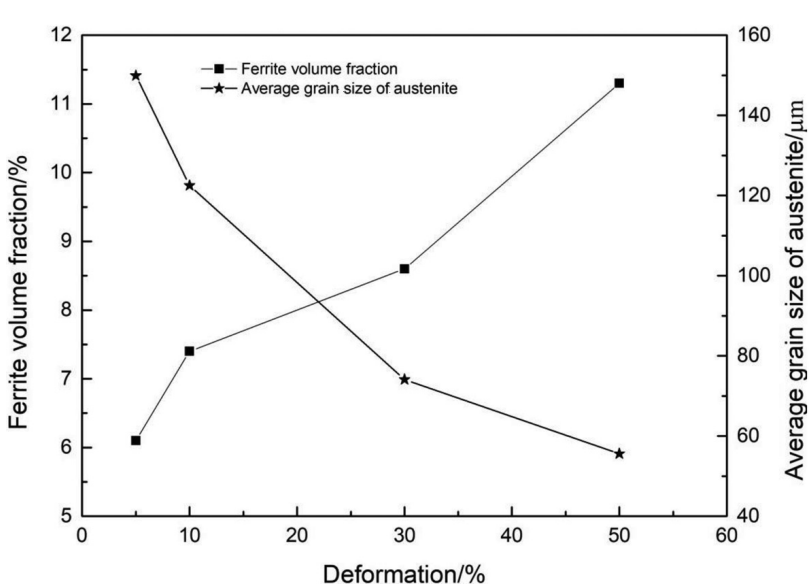

Figure 3: Statistical results for different deformations

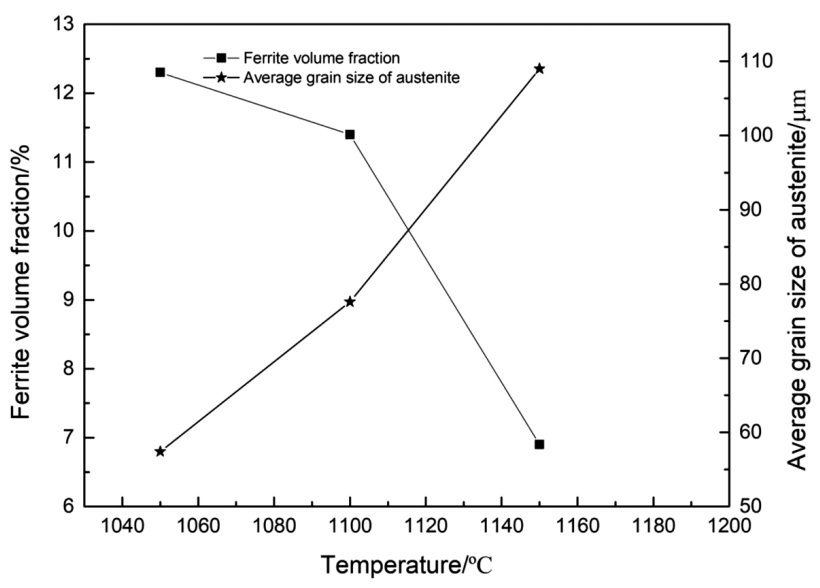

Figure 5: Statistical results for the different deformation temperatures
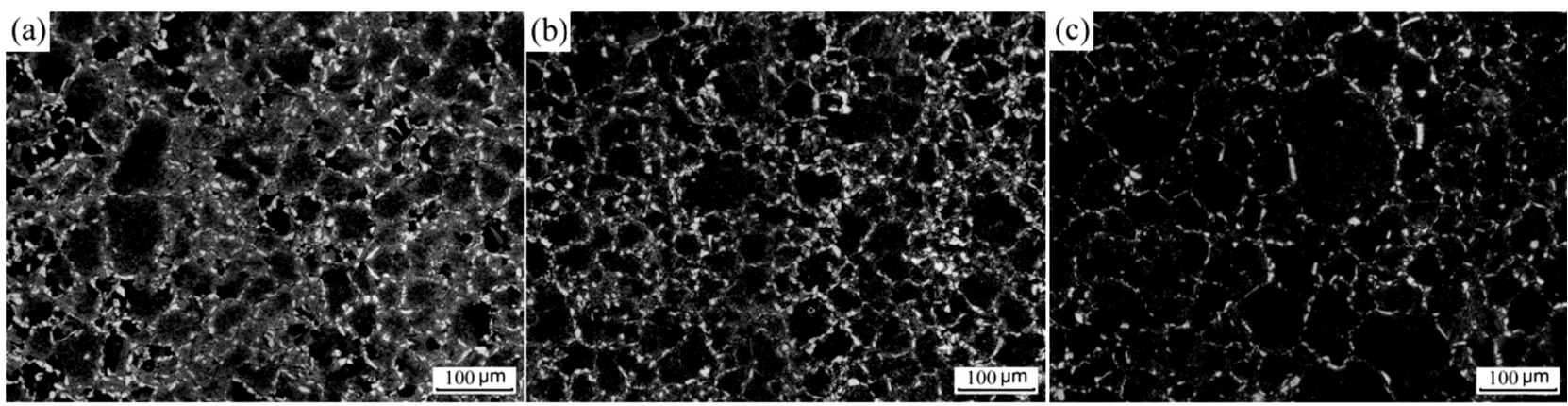

Figure 4: Microstructures for the different deformation temperatures: a) $1050{ }^{\circ} \mathrm{C}$, b) $1100{ }^{\circ} \mathrm{C}$, c) $1150{ }^{\circ} \mathrm{C}$ 

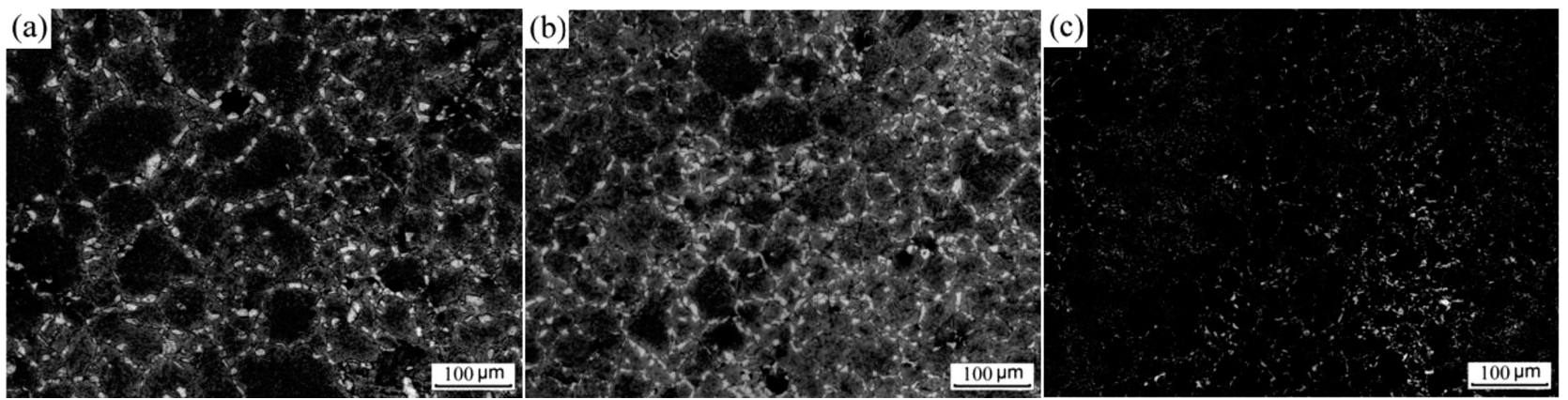

Figure 6: Microstructures for the different cooling rates: a) $0.1{ }^{\circ} \mathrm{C} \mathrm{s}^{-1}$, b) $0.3{ }^{\circ} \mathrm{C} \mathrm{s}^{-1}$, c) $1{ }^{\circ} \mathrm{C} \mathrm{s}^{-1}$

complete dynamic recrystallization occurred and the austenite grains grew.

When the temperature was low, the ferrite nucleation position increased, and thus the volume fraction of the ferrite increased. A small amount of intragranular ferrite (IGF) nucleated and grew at the defect position. The IGF can segment the austenite grains, refine the microstructure, and improve the toughness and plasticity of the steel. With the increasing of the temperature, the ferrite volume fraction decreased, and the grain size became non-uniform. When the temperature was $1150{ }^{\circ} \mathrm{C}$, the austenite recrystallized completely, and the residual in the microstructure was less. As a result, the ferrite nucleation position was less, and the volume fraction of the ferrite decreased.

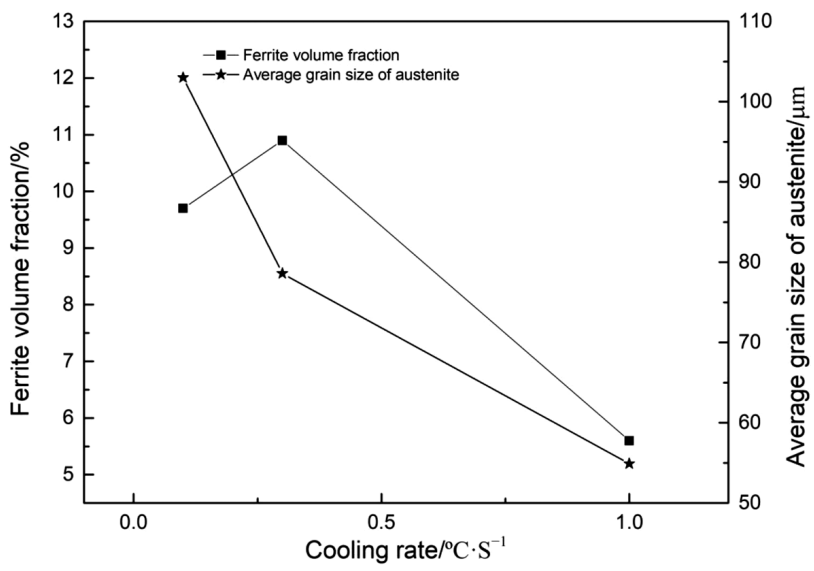

Figure 7: Statistical results for the different cooling rates

\subsection{Influence of cooling rate}

The microstructures for the different cooling rates are shown in Figure 6, and the statistical results are shown in Figure 7. The microstructure consists of ferrite and pearlite. With the increasing of the cooling rate, the average grain size of the austenite was refined from $103 \mu \mathrm{m}$ to $54.9 \mu \mathrm{m}$, and the volume fraction of the ferrite increased slightly and then decreased obviously.

The austenite grain size decreased with the increasing of the cooling rate. This is because the grains have no time to grow as the cooling rate increased. When the cooling rate increased from $0.1{ }^{\circ} \mathrm{C} \mathrm{s}^{-1}$ to $0.3{ }^{\circ} \mathrm{C} \mathrm{s}^{-1}$, the volume fraction of ferrite slightly increased, while the cooling rate increased from $0.3{ }^{\circ} \mathrm{C} \mathrm{s}^{-1}$ to $1^{\circ} \mathrm{C} \mathrm{s}^{-1}$, the volume fraction of ferrite decreased obviously. The volume fraction of ferrite was affected by the austenite grain size and the degree of under cooling. When the cooling rate was less than $0.3^{\circ} \mathrm{C} \mathrm{s}^{-1}$, the volume fraction of ferrite was mainly influenced by the nucleation rate. With the cooling rate increasing, the austenite grains were refined. With the refinement of the austenite grains, the nucleation sites of the ferrite increased, so the ferrite volume fraction increased. When the cooling rate was higher than $0.3{ }^{\circ} \mathrm{C} \mathrm{s}^{-1}$, the volume fraction of ferrite was mainly influenced by the degree of under cooling. With the cooling rate increasing, the volume fraction of ferrite decreased.

Figure 8 shows the pearlite morphology for the different cooling rates after $50 \%$ deformation at $1150{ }^{\circ} \mathrm{C}$. With the increasing of the cooling rate, the lamellar spacing of the pearlite was $243 \mathrm{~nm}, 221 \mathrm{~nm}$ and $189 \mathrm{~nm}$,
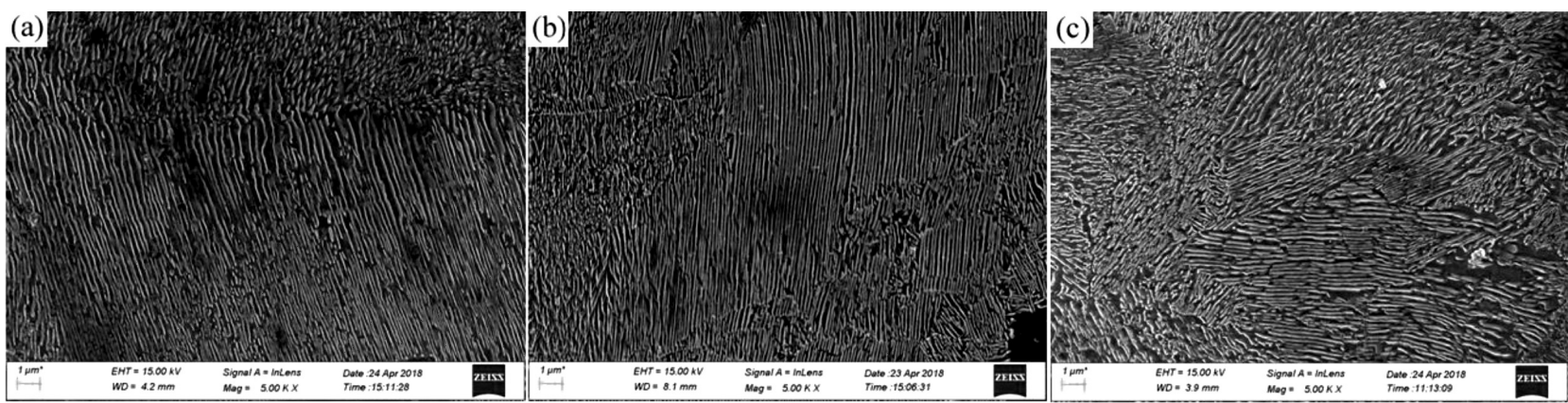

Figure 8: SEM photographs for the different cooling rates: a) $0.1{ }^{\circ} \mathrm{C} \mathrm{s}^{-1}$, b) $0.3{ }^{\circ} \mathrm{C} \mathrm{s}^{-1}$, c) $1{ }^{\circ} \mathrm{C} \mathrm{s}^{-1}$ 
respectively. Fine and uniform pearlitic lamella can enhance the strength and toughness of the material. ${ }^{23}$

It is clear that when the cooling rate was $0.1{ }^{\circ} \mathrm{C} \mathrm{s}^{-1}$, the pearlite laminar spacing was relatively coarse. When the cooling rate was $1{ }^{\circ} \mathrm{C} \mathrm{s}^{-1}$, the pearlite lamella were fine, but with distortion, which can increase the strength, but decrease the toughness. When the cooling rate was $0.3{ }^{\circ} \mathrm{C} \mathrm{s}^{-1}$, the pearlite lamella were not only fine, but also distributed uniformly.

The ferrite content and the pearlite morphology and size were related to the cooling rate of the phase change. In order to obtain a reasonable ferrite content and the uniform and fine lamellar spacing of pearlite, the cooling process should be controlled by section. Before the ferrite transformation, the cooling rate should be quick enough to restrain the growth of the austenite grains. During the ferrite transformation, especially in the range of the pearlite lower limit temperature from $620{ }^{\circ} \mathrm{C}$ to $580{ }^{\circ} \mathrm{C}$ (shown in Figure 1), the cooling rate should be near $0.3{ }^{\circ} \mathrm{C} \mathrm{s}^{-1}$. A reasonable ferrite content can be obtained. The uniform and fine lamellar spacing can also be formed and abnormal structures, such as bainite and martensite, can be avoided (Figure 1).

\subsection{Numerical simulation results}

Deformation depends on the design of the final forging cavity. As was shown in the thermal simulation experiment, it can be seen that the increase of the deformation is beneficial to the grain refinement and the formation of ferrite. For the complex-shape crankshaft forging, the final forging deformation must be designed reasonably, and the forging equipment cannot be overloaded. The temperature depends on the heating temperature of the blank. The lower forging temperature is beneficial to the microstructure refinement and the ferrite formation, but not conducive to the filling of the cavity. The cooling rate can be controlled after forging and was not considered in the numerical simulation.

The 465-type crankshaft was chosen as the subject of the research, and the forging equipment was the $4000 \mathrm{t}$

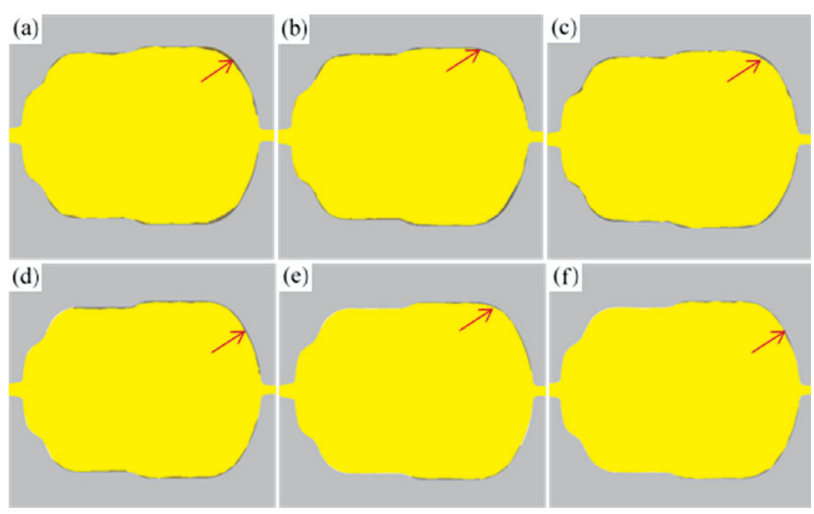

Figure 9: Balance block forming results for the different conditions: a) $1050{ }^{\circ} \mathrm{C}$, deformation $10 \%$, b) $1050{ }^{\circ} \mathrm{C}$, deformation $15 \%$, c) 1050 ${ }^{\circ} \mathrm{C}$, deformation $20 \%$, d) $1100{ }^{\circ} \mathrm{C}$, deformation $10 \%$, e) $1100{ }^{\circ} \mathrm{C}$, deformation $15 \%$, f) $1100{ }^{\circ} \mathrm{C}$, deformation $20 \%$ hot die forging press. The numerical simulation scheme is shown in Table 3. Because the balance block is the most deformed part of the crankshaft, so the deformation in the numerical simulation scheme was the crosssection reduction rate of the balance block, and the temperature was the start forging temperature. The simulation software was Deform-3D. The simulated parameters and boundary conditions were chosen according to the forging parameters. The initial temperature of the die was $250{ }^{\circ} \mathrm{C}$, and the environment temperature was 20 ${ }^{\circ} \mathrm{C}$. The forging speed of the die was $240 \mathrm{~mm} \cdot \mathrm{s}^{-1}$. The friction coefficient between the blank and the die was 0.3 . The heat-transfer coefficient between the blank and die was $11 \mathrm{~N} /\left(\mathrm{s} \mathrm{mm} \cdot{ }^{\circ} \mathrm{C}\right)$, and the heat-transfer coefficient between the blank and the air was $0.02 \mathrm{~N} /\left(\mathrm{s} \mathrm{mm} \cdot{ }^{\circ} \mathrm{C}\right)$.

Table 3: Numerical simulation scheme

\begin{tabular}{|c|c|c|}
\hline No. & Deformation $/ \%$ & Temperature $/{ }^{\circ} \mathrm{C}$ \\
\hline 1 & 20 & 1050 \\
\hline 2 & 20 & 1100 \\
\hline 3 & 20 & 1150 \\
\hline 4 & 15 & 1050 \\
\hline 5 & 15 & 1100 \\
\hline 6 & 15 & 1150 \\
\hline 7 & 10 & 1050 \\
\hline 8 & 10 & 1100 \\
\hline 9 & 10 & 1150 \\
\hline
\end{tabular}

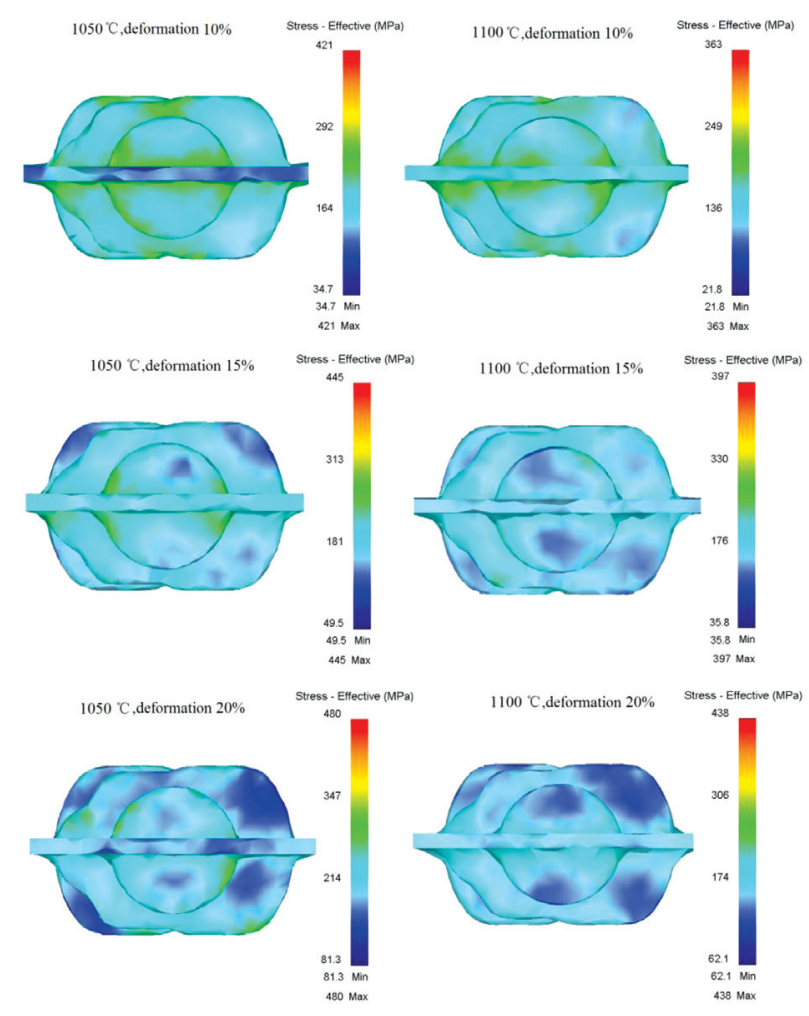

Figure 10: Stresses under different conditions 

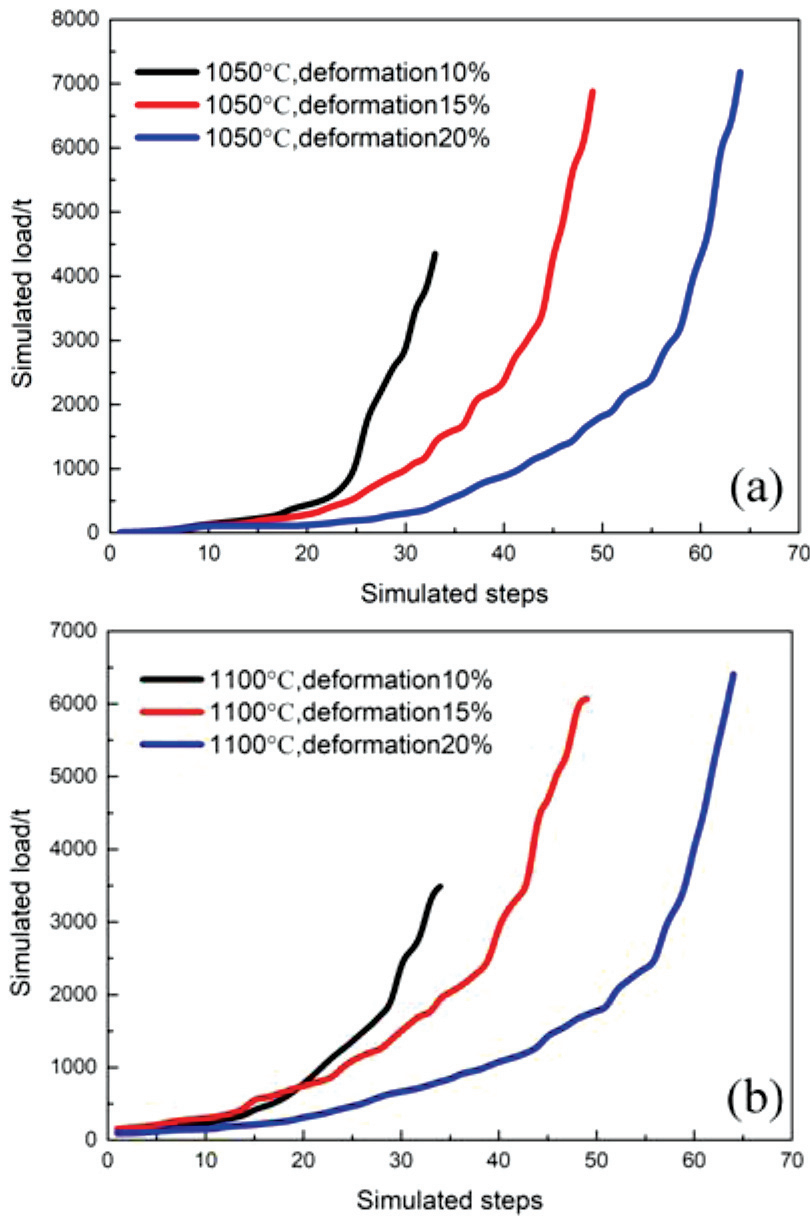

Figure 11: Simulated load for the different conditions: a) $1050{ }^{\circ} \mathrm{C}$, b) $1100{ }^{\circ} \mathrm{C}$

\subsection{Forgings forming analysis}

The crankshaft balance block has the shape of a thin plate, which was the most difficult to fully form. The simulation results of the different conditions are shown in Figure 9, and the unfilled parts are marked with red arrows. The stresses of the different conditions are shown in Figure 10. The simulated loads for the different conditions are shown in Figure 11.

It is clear that when the temperature was $1050{ }^{\circ} \mathrm{C}$, the cavity was unfilled, and when the deformation was $10 \%$ it was most serious. When the temperature was $1100{ }^{\circ} \mathrm{C}$, the cavity was also unfilled, but the filling effects were better than that at $1050{ }^{\circ} \mathrm{C}$. When the forging was deformed $15 \%$ at $1100{ }^{\circ} \mathrm{C}$, the cavity was almost fully filled.

At the same temperature, the stress and the load increased with the increasing of the deformation. For the same deformation, the stress and the load decreased with the increasing of the temperature. When the temperature was $1050{ }^{\circ} \mathrm{C}$, the equipment was overloaded, while the equipment was not overloaded when the forging was deformed $10 \%$ at $1100{ }^{\circ} \mathrm{C}$.

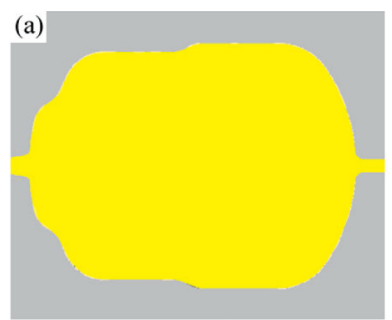

(c)
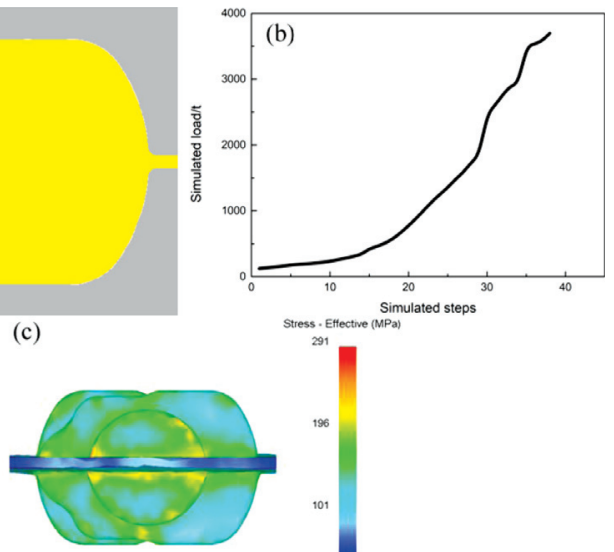

${ }^{106}$

Figure 12: Process optimization simulation: a) balance block forming results, b) simulated load, c) stress

\subsection{Optimization simulation}

According to the numerical simulation results, the forging process for the crankshaft was optimized. The crankshaft forging temperature was $1120{ }^{\circ} \mathrm{C}$, and the deformation was $12 \%$. The simulation results are shown in Figure 12. It can be seen that the cavity was fully filled. The maximum stress was only $291 \mathrm{MPa}$. The simulated load was $3740 \mathrm{t}$, and the equipment was not overloaded.

\section{CONCLUSIONS}

(1) The deformation and the deformation temperature had an important influence on the microstructure of the NQ\&T 1538MV steel. The microstructure can be refined by increasing the deformation and reducing the deformation temperature. To obtain fine grains, a critical deformation must be achieved.

(2) The ferrite content and the pearlite morphology and size were related to the cooling rate of the phase change. In order to obtain a reasonable ferrite content and the uniform and fine lamellar spacing of the pearlite, the cooling process should be controlled by section.

(3) In order to ensure full filling of the cavity and prevent overloading of the forging equipment, the finished forging deformation of the crankshaft should be reasonable, and the temperature should not be too low. The optimized deformation temperature of the 465-type crankshaft was $1120{ }^{\circ} \mathrm{C}$, and the deformation of the balance block was $12 \%$.

\section{Acknowledgement}

This work was supported by State Key Lab of Advanced Metals and Materials. 


\section{REFERENCES}

${ }^{1}$ P. Hyounsoo, S. K. Yong, C. J. Seung, Development of fracture split steel connecting rods, Innorotion of Steel Bar and Steel Plant, (2003), 91-95, doi:10.4271/2003-01-1309

${ }^{2}$ F. A. Khalid, Precipitation and compositional changes in the structural phases of microalloyed automotive steels, Materials Science and Engineering, 325 (2002) 1/2, 281-285, doi:10.1016/S09215093(01)01471-X

${ }^{3}$ K. D. Chang, P. Wang, W. P. Liu, Development status and application prospect of non-quenched tempered steel, Heat Treatment of Metals, 36 (2011) 3, 80-85, doi:10.13251/j.issn.0254-6051.2011.03.010

${ }^{4}$ V. Ollilainen, W. Kasprzak, L. Holappa, The effect of silicon vanadium and nitrogen on the microstructure and hardness of air cooled medium carbon low alloy steels, Journal of Materials Processing Technology, 134 (2003) 3, 405-412, doi:10.1016/S0924-0136(02) 01131-7

${ }^{5}$ X. W. Yang, Q. Tu, J. Liu, Study on process of eliminating banded microstructure of non-quenched and tempered steel C38N2 for crankshaft, Hot Working Technology, (2017) 6, 226-229, doi:10.14158/j.cnki.1001-3814.2017.06.061

${ }^{6} \mathrm{Y}$. Gao, Application of $38 \mathrm{MnSiV} 5$ non-quenched and tempered steel in engine crankshaft, Modern Components, 3 (2018), 33-36, doi:10.16173/j.cnki.ame.2018.03.009

${ }^{7}$ X. S. Ying, X. G. Dong, B. Zhou, Study on cooling process of $38 \mathrm{MnNS} 5$ non-quenched and tempered steel crankshaft after forging, Hot Working Technology, (2017) 4, 249-250, doi:10.14158/ j.cnki.1001-3814.2017.04.068

${ }^{8}$ L. D. Liu, Development and production of non-quenched and tempered steel for crankshaft by large size concast blooms, Special Steel Technology, (2013) 1, 16-18, doi:10.3969/j.issn.16740971.2013.01.006

${ }^{9}$ Y. Zhang,Y. H. Huang, H.Zhai, A new high quality non-quenching and tempering steel, Journal of Iron and Steel Research, 17 (2005) 2, 52-56, doi:10.3321/j.issn:1001-0963.2005.02.012

${ }^{10}$ Y. B. Chen, W. Ma, K. Jin, Development on improving the strength \& toughness of microalloyed steels, Materials for Mechanical Engineering, 25 (2000) 8, 1-6, doi:10.3969/j.issn.1000-3738.2001. 03.001

${ }^{11}$ M. T. Ma, Recent progress and applications of micro alloying un-hardened-and-tempered steels to automotive industry, Materials for Mechanical Engineering, 30 (2006) 5, 5-8, doi:10.3969/ j.issn.1000-3738.2006.05.002

${ }^{12}$ D. H. Chen, Z. M. Wang, W. L. Xie, Strengthening and toughening of non-quenched and tempered steel, Heat Treatment of Metals, 35 (2010) 6, 76-79, doi:10.13251/j.issn.0254-6051.2010.06.033
${ }^{13}$ C. Zhang, L. W. Zhang, S. D. Gu, Microstructure evolution of 38MnVS6 non-quenched steel bar during cooling process after hot rolling, Heat Treatment of Metals, 42 (2017) 2, 207-210, doi:10.13251/j.issn.0254-6051.2017.02.044

${ }^{14}$ X. M. Zhao, X. Y. Mao, L. Cai, Effect of controlled cooling after forging on formation of intragranular ferrite and toughness for a $38 \mathrm{MnVS}$ steel, Transactions of Materials and Heat Treatment, 34 (2013) 11, 114-118, doi:10.13289/j.issn.1009-6264.2013.11.022

${ }^{15}$ Y. H. Dong, Y. J. Zhang, X. X. Wei, Effect of thermo mechanical control process on microstructure and properties of a non-quenched and tempered steel, Transactions of Materials and Heat Treatment, 33 (2012) 7, 94-99, doi:10.13289/j.issn.1009-6264.2012.07.029

${ }^{16}$ Y. F. Fan, X. Q. He, Effects of heating temperature and controlled cooling on microstructure and properties of HN2154 non-quenched and tempered steel, Heat Treatment of Metals, 42 (2017) 10, 108-111, doi:10.13251/j.issn.0254-6051.2017.10.023

${ }^{17}$ S. S. Zhu, Z. Z. Wang, X. Y. Mao, A review about strengthening-toughening technologies for ferrite-pearlite non-quenched and tempered steels, Materials Review, 30 (2016) 9, 122-126, doi:10.11896/j.issn.1005-023X.2016.09.020

${ }^{18}$ Y. Shi, G. W. Dai, Z. G. An, Continuous cooling transformation of supercooled austenite of 46MnVS6 non-quenched and tempered steel, Materials for Mechanical Engineering, 42 (2018) 2, 43-46, doi:10.11973/jxgecl201802010

${ }^{19} \mathrm{G}$. Wei, Effect of controlled cooling after rolling on microstructure and properties of microalloyed medium carbon steel 36 MnVS6, Heat Treatment of Metals, 41 (2016) 10, 176-179, doi:10.13251/ j.issn.0254-6051.2016.10.038

${ }^{20}$ S. L. Chen, W. J. Hui, C. W. Shao, Effect of controlled cooling on microstructure and properties of medium-carbon high-vanadium microalloyed steel, Iron \& Steel, 50 (2015) 8, 77-82, doi:10.13228/ j.boyuan.issn0449-749x.20140691

${ }^{21}$ D. L. Liu, L. Tan, H. X. Yang, Microalloy of ferrite-pearlite nonquenched and tempered steels and their forging technology, Journal of Iron and Steel Research, 25 (2013) 12, 41-46, doi:10.13228/ j.boyuan.issn1001-0963.2013.12.005

${ }^{22}$ X. Q. Zha, W. J. Hui, Q. L. Yong, High-cycle fatigue fracture behavior of ferrite-pearlite type microalloyed steels, Chinese Journal of Materials Research, 22 (2008) 6, 634-638, doi:10.3321/j.issn:10053093.2008.06.015

${ }^{23}$ Y. Liang, L. F. Yu, Y. L. Liang, Relationship between microstructure and tensile properties of a pearlitic steel, Transactions of Materials and Heat Treatment, 34 (2013) 7:73-77, doi:10.13289/j.issn.10096264.2013 .07 .025 